\title{
Characteristics of Vertical E-field Waveforms Associated with Return-strokes on Southeastern Sea of Kyushu
}

\author{
Koji Michishita Member (Shizuoka University, tekmich@ipc.shizuoka.ac.jp) \\ Nozomu Nagatsuna Student Member (Shizuoka University, f0631049@ipc.shizuoka.ac.jp) \\ Tomomasa MurakamiＭember（Shizuoka University, f0311054@ipc.shizuoka.ac.jp) \\ Takashi Harada Member (Kyushu Electric Power Co., Inc., takashi_harada@kykuden.co.jp)
}

Keywords: lightning, return stroke, peak current, electric field, attachment process

The lightning detection network has widely spread, and the research has actively been done by using the location of the lightning striking point and/or the peak current obtained by the network. Recently, Cummins et al. have clarified that the maritime return-stroke current on the southern and eastern sea of the USA is higher than the inland return-stroke current by using the results obtained by NLDN.

Figure 1 shows the area subject to analysis of return-stroke current peaks obtained by JLDN. Figure 2 shows $50 \%$ values of estimated peak current of inland and maritime strokes. In the case of negative first strokes, the maritime return-stroke current is higher than the inland stroke current in contrast to the cases of negative subsequent and positive first strokes. This is similar to the result on the southern and eastern part of the USA obtained by NLDN.

The authors also compare the characteristics of the electric field waveforms associated with maritime negative and positive strokes in summer. The return strokes are categorized in reference to the pulses in the time derivative of the E-field waveforms in the time

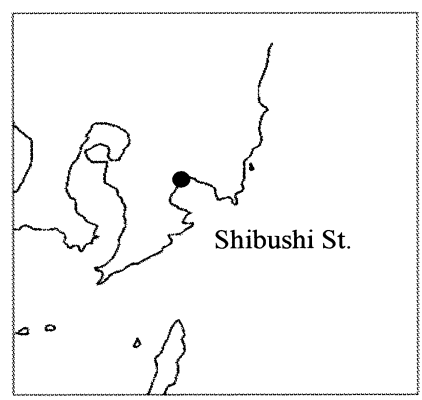

Fig. 1. Areas subject to analysis of return-stroke current peaks obtained by JLDN

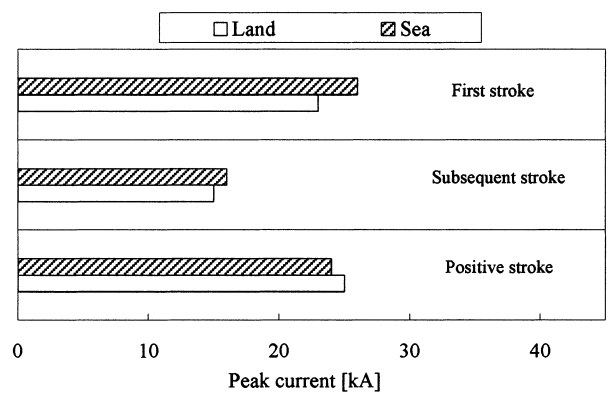

Fig. 2. $50 \%$ value of estimated peak current of inland and maritime strokes range from -4 to 1 microseconds of the dominant peak. That is, if the subsidiary pulse whose amplitude is at least $30 \%$ of the amplitude of the dominant peak appears within $\pm 1 \mu$ s of the dominant peak, the event will be termed "Type B" strokes. The events producing one or more pulses in the interval from $-4 \mu$ s to $-1 \mu$ s before the dominant peak with no pulses within $\pm 1 \mu$ s will be termed "Type C" strokes. The events having a single large pulse in the time interval from $-4 \mu$ s to $+1 \mu$ s corresponding to the fast-transition in E-field, will be termed "Type A" strokes.

The statistics of the peak E-fields associated with negative first strokes dependent on the categorized types are shown in Table 1. The frequency of occurrence for each type agrees with the results obtained in Florida with the discrepancy of less than $6 \%$. The peak of the E-field waveform normalized at the distance of $100 \mathrm{~km}$ by using the inversely proportional relationship to the distance is also shown in Table 1. Both the averages and the $50 \%$ values for Type $\mathrm{B}$ and Type $\mathrm{C}$ are higher than those for Type A by 20 to $30 \%$. In the cases of negative subsequent strokes and positive strokes, the frequency of occurrence for Type A strokes is $91 \%$ and $80 \%$, respectively, in contrast to the negative first strokes. Therefore, it is pointed out that high frequency of occurrence of Type B and Type $\mathrm{C}$ strokes might be one of cases of the observed difference between the maritime and inland stroke currents in the case of negative first strokes.

Table 1. Parameters of E-field and dE/dt waveforms associated with negative first strokes

\begin{tabular}{|c|c|c|c|c|}
\hline & & Type A & Type B & Type C \\
\hline & number & $\begin{array}{c}75 \\
{[45]}\end{array}$ & $\begin{array}{l}110 \\
{[49]}\end{array}$ & $\begin{array}{c}83 \\
{[37]}\end{array}$ \\
\hline riequency & ratio[\%] & $\begin{array}{c}28 \\
{[34]} \\
\end{array}$ & $\begin{array}{c}41 \\
{[37]} \\
\end{array}$ & $\begin{array}{c}31 \\
{[28]} \\
\end{array}$ \\
\hline \multirow{4}{*}{$\begin{array}{c}100 \mathrm{~km} \mathrm{E} \\
{[\mathrm{V} / \mathrm{m}]}\end{array}$} & $\begin{array}{c}\text { Average } \\
\text { (Standard deviation) }\end{array}$ & $\begin{array}{c}15(5.6) \\
{[7.6(2.8)]}\end{array}$ & $\begin{array}{r}20(6.1) \\
{[11(5.5)]}\end{array}$ & $\begin{array}{r}19(7.1) \\
{[8.7(3.7)]}\end{array}$ \\
\hline & $90 \%$ value & 9.3 & 11 & 10 \\
\hline & $50 \%$ value & $\begin{array}{c}13 \\
{[7.4]}\end{array}$ & $\begin{array}{c}18 \\
{[9.0]}\end{array}$ & $\begin{array}{c}16 \\
{[7.6]}\end{array}$ \\
\hline & $10 \%$ value & 23 & 27 & 31 \\
\hline \multirow{4}{*}{$\begin{array}{c}100 \mathrm{~km} \\
\mathrm{dE} / \mathrm{dt} \\
{[\mathrm{V} / \mathrm{m} / \mu \mathrm{s}]}\end{array}$} & $\begin{array}{c}\text { Average } \\
\text { (Standard deviation) }\end{array}$ & $\begin{array}{c}32 \\
(11)\end{array}$ & $\begin{array}{c}33 \\
(11)\end{array}$ & $\begin{array}{c}32 \\
(12)\end{array}$ \\
\hline & $90 \%$ value & 18 & 19 & 18 \\
\hline & $50 \%$ value & 32 & 31 & 31 \\
\hline & $10 \%$ value & 47 & 45 & 50 \\
\hline $\begin{array}{c}\text { Distance } \\
{[\mathrm{km}]}\end{array}$ & $\begin{array}{c}\text { Average } \\
\text { (Standard deviation) }\end{array}$ & $\begin{array}{r}82 \\
(33) \\
\end{array}$ & $\begin{array}{r}94 \\
(32) \\
\end{array}$ & $\begin{array}{r}95 \\
(32) \\
\end{array}$ \\
\hline
\end{tabular}




\title{
九州南東海上に発生した雷に伴う垂直電界波形の特徵
}

\author{
正 員 道下 幸志* 学生員 長綱 望* \\ 正員 村上 智允* 正員 原田 貴司**
}

\section{Characteristics of Vertical E-field Waveforms Associated with Return-strokes on Southeastern Sea of Kyushu}

Koji Michishita*, Member, Nozomu Nagatsuna*, Student Member,

Tomomasa Murakami*, Member, Takashi Harada**, Member

The lightning detection network has widely spread, and the research has actively been done by using the location of the lightning striking point and/or the peak current obtained by the network. Recently, Cummins et al. have clarified that the maritime return-stroke current on southern and eastern sea of the USA is higher than the inland return-stroke current by using the results obtained by NLDN. In this paper we compare the inland and the maritime return-stroke current in southeastern part of Kyushu by using the data obtained by JLDN. In case of negative first strokes, the maritime return-stroke current is higher than the inland stroke current in contrast to the cases of negative subsequent and positive first strokes. The authors investigate characteristics of the electric field waveforms associated with maritime negative and positive strokes in summer. As a result, it is pointed out that high frequency of occurrence of time-derivative of E-field waveforms having multiple pulses close to the dominant peak might be one of causes of the observed difference between the maritime and inland stroke currents in case of negative first strokes.

キーワード : 雷, 帰還雷撃, 電流波高値, 電界, 結合過程

Keywords: lightning, return stroke, peak current, electric field, attachment process

\section{1. はじめに}

電力設備の効果的な雷害対策を施す際, 雷性状を把握す る事は重要である。現在では国内外で落雷位置標定システ ム $(\mathrm{LLS})^{(1)(2)}$ が用いられ，このシステムにより得られた結 果を用いて，落雷密度の季節変化や帰還雷撃電流パラメー 夕についての報告がなされている(3)〜(6)。文献 (7) では，ア メリカ南部及び東部での観測結果に基づいて，負極性第一 帰還雷撃の推定電流波高值は，海上に発生した雷撃の方が 陸上のものより大きく, 海と陸の境界線で明白な変化が確 認出来るが，負極性後続雷撃及び正極性雷撃については異 なる傾向を示すことを指摘し，この現象の主要な原因は，下 向きのリーダと上向きのリーダの結合過程 ${ }^{(8)}$ にあると推定 している。

\footnotetext{
* 静岡大学大学院工学研究科

于 432-8561 浜松市中区城北 3-5-1

Dept. of Electrical \& Electronic Eng., Shizuoka University

3-5-1, Johoku, Naka-ku, Hamamatsu 432-8561

** 九州電力 (株) 総合研究所

干 815-8520 福岡市南区 2-1-47

Research Labs., Kyushu Electric Power Co.

2-1-47, Shiobara, Minami-ku, Fukuoka 815-8520
}

文献 (9) では，文献(10) や文献(11) に示された電界波形 (E 波形) とその時間微分波形 ( $\mathrm{dE} / \mathrm{dt}$ 波形) の微細構造を 検討し, 海上に発生した負極性第一帰還雷撃に伴う電界波 形の内, 約 $37 \%$ は $\mathrm{dE} / \mathrm{dt}$ 波形の中で最大ピークの $1 \mu \mathrm{s}$ 前後 に別の大きなピークを含み，これらの電界波高值の平均值 は別のピークを含まないものの值より $36 \%$ 大きい事を明ら かにした。文献(9) では, $\mathrm{dE} / \mathrm{dt}$ 波形内の複数のパルスは, 1 つの放電路に複数の電流パルスが発生した場合や, 複数 の放電路が形成された場合に発生するものと推定している。 本報告では, 日本の雷放電位置標定ネットワーク ${ }^{(12)}$ (JLDN) で得られたデー夕を用いて, 九州南東部地域にお ける陸上及び海上に発生した負極性第一雷撃，負極性後続 雷撃及び正極性第一雷撃の電流波高值を比較する。また, この地域で夏季に熱雷に伴って発生した電界波形の特徵を, 負極性第一雷撃，負極性後続帰還雷撃及び正極性第一雷撃 の各々について検討した結果について述べる。

\section{2. 電流波高值の比較}

〈2·1〉解析対象図 1 に, JLDNにより得られた帰還 雷撃電流波高值の解析対象とした地域を示す。図 1 に示す エリアの面積は, 約 $36000 \mathrm{~km}^{2}$ （南北及び東西約 $190 \mathrm{~km}$ ) 


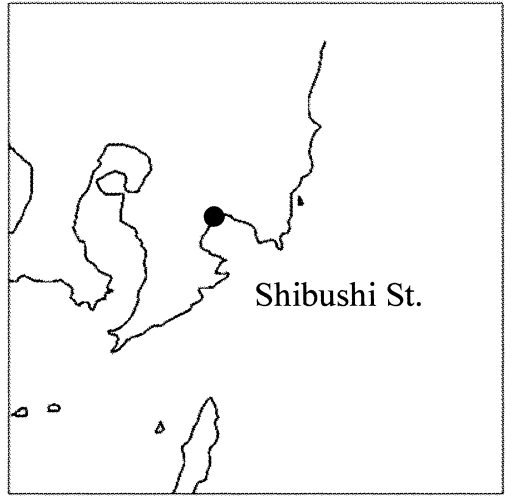

図 1 JLDNにより得られた帰還雷撃電流波高值 の解析対象地域

Fig. 1. Areas subject to analysis of return-stroke current peaks obtained by JLDN.

である。JLDNにより 2006 年の 7 9 月にこのエリアに位 置標定された雷撃を解析対象とした。また，JLDNで推定 された電流波高值が, 負極性雷撃については $10 \mathrm{kA}$ 以下, 正極性雷撃については $15 \mathrm{kA}$ 以下の雷撃は雲放電である可 能性があるため，それらは解析対象外とした。JLDN で得 られた負極性雷撃のデータの内, 先行する雷撃から $200 \mathrm{~ms}$ 以内, かつ雷撃点間の距離が $1 \mathrm{~km}$ 以内に発生したものは後 続雷撃の可能性があるため, それ以外のデー夕を負極性第 一雷撃によるものと見なした。負極性後続雷撃は, 先行す る雷撃との標定位置の差が誤差長径より小さく，また，先 行する雷撃から $30 \mathrm{~ms}$ 以内に発生し， かつ雷撃点間距離が $100 \mathrm{~m}$ 以内の雷撃とした。正極性雷撃に関しては後続雷撃 が発生することはまれであるため，全て第一雷撃によるも のと考えた。

$\langle\mathbf{2} \cdot \mathbf{2}\rangle$ 推定電流波高值 図 2 に, 負極性第一雷撃, 負 極性後続雷撃及び正極性第一雷撃の電流波高值の $50 \%$ 值を 比較したものを示す。デー夕数は，海上雷撃の場合が負極 性第一雷撃, 負極性後続雷撃及び正極性雷撃で各々 25607, 65，1657であり，陸上雷撃の場合が各々 $16726 ， 58 ， 861$ である。負極性第一雷撃の電流波高值の 50\%值は陸上雷撃 が $23 \mathrm{kA}$ で，海上雷撃の場合の $26 \mathrm{kA}$ が 13\%程度大きい。 これに対して負極性後続雷撃の $50 \%$ 值は，陸上 $15 \mathrm{kA}$ と海 上 $16 \mathrm{kA}$ と大きな差は見られない。また，正極性雷撃では 陸上 $25 \mathrm{kA}$ と海上 $24 \mathrm{kA}$ とやはり大きな差は見られない。

負極性第一雷撃のみが，雷撃点が陸上か或いは海上かで 電流波高值に相違が認められ，負極性後続雷撃や正極性雷 撃で電流波高值に大きな相違が認められないのは，アメリ カの雷放電位置標定ネットワーク（NLDN）によりアメリ カ南部及び東部で得られたのと同様の結果となっている(7)。 一方，NLDNによる観測結果(7)では，海上への雷撃が陸上 への雷撃よりも約 25\%大きくなっており，図 2 に示した約 13\%の相違よりも 2 倍程度大きくなっている。これは，文 献 (7) で観測対象となっているアメリカ南部及び東部（南 北 $1700 \mathrm{~km}$ ，東西 $2200 \mathrm{~km}$ ）の海岸線に沿っての平均的な

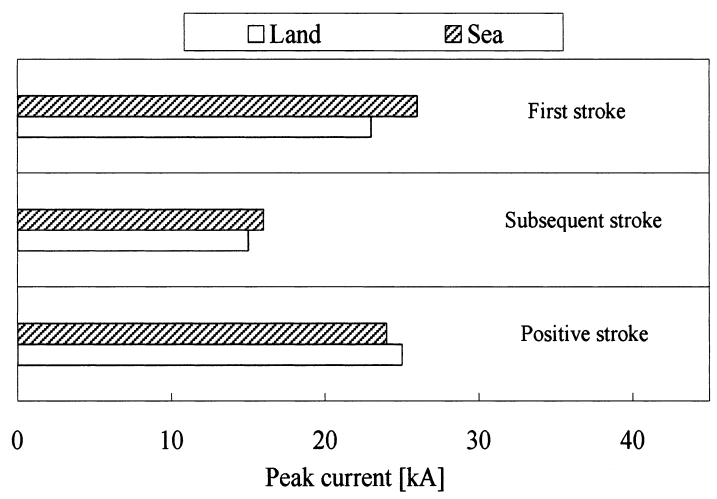

図 2 陸上及び海上に発生した雷撃の電流波高值

Fig. 2. Estimated peak current of inland and maritime strokes.

雷性状が，九州（南北及び東西約 $190 \mathrm{~km}$ ）南東部の雷性状 とは異なっている事や, 文献 (7) では数 $\mathrm{kA}$ と電流值の小さ い雷撃も対象としているのに対して, 本論文では $10 \mathrm{kA}$ 以 上の雷撃のみを対象としたことで，海上への雷撃と陸上へ の雷撃電流の推定值の相違が見かけ上小さくなったことが 原因と考えられるが，原因の究明や各要因による影響の度 合い等の詳細については，今後の課題とする。

\section{3. 海上に発生した落雷に伴う電界波形の解析}

$\langle\mathbf{3} \cdot 1\rangle$ 解析対象 著者らは, 九州南部の 4 地点で雷に 伴う電界観測を行っており, この内の 2 地点では磁界の観 測も行っている ${ }^{(13)}$ 。雷撃に伴って発生した電磁界波形を高 周波成分まで精度良く測定するためには，電磁波が陸上を 伝搬することによる高周波成分の減衰の影響を可能な限り 小さくする必要がある。よって本論文では，海岸線から約 $300 \mathrm{~m}$ の場所に位置する観測局 (志布志局) のデー夕を使用 した。この観測局には 2 つの電界記録システムがある。一 つのシステムでは, $1.8 \mathrm{kHz} \sim 2.5 \mathrm{MHz}$ の周波数帯域で測定 された電界を，分解能 12 ビット，サンプリング時間 $40 \mathrm{ns,}$ 記録時間 $160 \mathrm{~ms}$ のディジタイザにより記録している。もう 一つのシステムでは, $1 \mathrm{kHz} \sim 10 \mathrm{MHz}$ の周波数帯域で測定 された電界を，分解能 10 ビット，サンプリング時間 $40 \mathrm{~ns}$, 記録時間 $8 \mathrm{~ms}$ のディジタイザにより記録している。解析 対象とした負極性第一雷撃及び正極性雷撃のデー夕は，す べて後者のシステムにより観測されたもので，負極性後続 雷撃のデー夕は，比較的記録時間の長い前者のシステムに よって得られたものである。

$\langle\mathbf{3 \cdot 2}\rangle$ 垂直電界波形の分類 志布志局で観測された 垂直電界波形から電界の時間微分波形を計算し, 計算され た波形を文献 (9) の基準に従って分類する。文献 (9) では, 解析対象の $\mathrm{dE} / \mathrm{dt}$ 波形のピーク時刻を 0 とし, $-4 \sim 1 \mu \mathrm{s}$ の 間に発生したピーク值の $10 \%$ 以上の波高值をもつパルスに 注目している。本報告では， $\mathrm{dE} / \mathrm{dt}$ 波形の $\mathrm{S} / \mathrm{N}$ 比が低いた め, 最大ピーク值の $30 \%$ 以上の波高值をもつパルスに着目 した。 

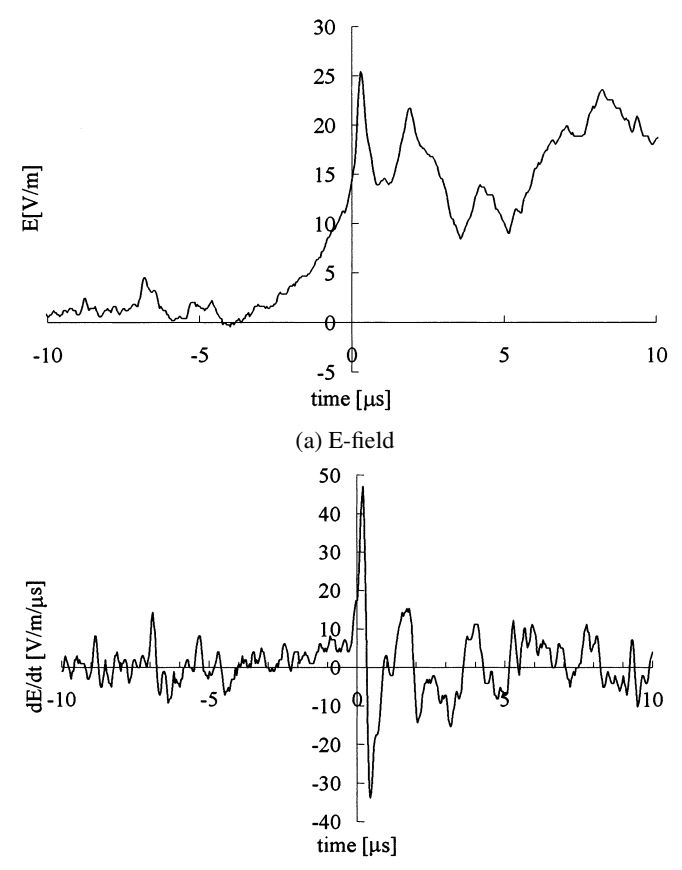

(b) Time derivative of E-field

図 3 Type A の電界波形及び電界時間微分波形

Fig. 3. An example of E-field and its time-derivative waveforms associated with "Type A" stroke.

-4 1 $\mu \mathrm{s}$ の時間帯に, 最大ピーク值の $30 \%$ 以上の波高 值をもつパルスが存在しない場合，その雷撃を Type A と 分類する。図 3 に Type A 波形の一例を示す。また，最大 ピーク時刻の $\pm 1 \mu \mathrm{s}$ 以内に, 該当するパルスが存在する場 合, Type B と分類する。図 4 に Type B 波形の一例を示す。 さらに，最大ピーク時刻の $\pm 1 \mu \mathrm{s}$ 以内に該当するパルスが 無く， $-4 \sim-1 \mu \mathrm{s}$ 間にパルスが存在する場合，その波形を Type C に分類する。図 5 に Type C 波形の一例を示す。

これらの時間微分波形の発生要因の解明は今後の課題の 一つであるが，下向きに進展してきたリーダに対応した上 向きのリーダの開始から帰還雷撃の開始まで短時間継続す る，結合過程（attachment process） ${ }^{(8)}$ にその原因となる現 象が発生していると推定されている(9)。文献 (9)には，結合 過程で，下向きに進展するリーダや海上から上向きに進展 するリーダが間欠的に進展した場合や，同じく結合過程に 枝分かれ等により複数の放電路が形成され，それらを帚還 雷撃電流が流れた場合などが可能性のある要因として挙げ られている。著者等は，前者は Type C の，後者は Type B の電界の時間微分波形が発生する要因となっているのでは ないかと考えている。

熱雷と界雷では雷性状が異なることが予測されるため, 本論文では, 雷撃点が海上にあり, 陸上の伝搬距離が $385 \mathrm{~m}$ 以下で，かつ，熱雷に伴って発生した電界波形のみを解析 対象とした。

$\langle\mathbf{3} \cdot \mathbf{3}\rangle$ 負極性第一帰還雷撃 表 1 に, 負極性第一雷 撃について，タイプ別に分類された電界波形及び $\mathrm{dE} / \mathrm{dt}$ 波 形のパラメー夕を示す。また，文献(9) で得られた值も表 1

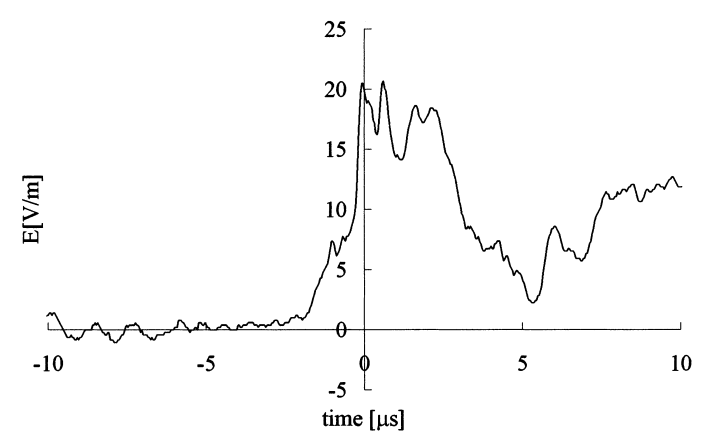

(a) E-field

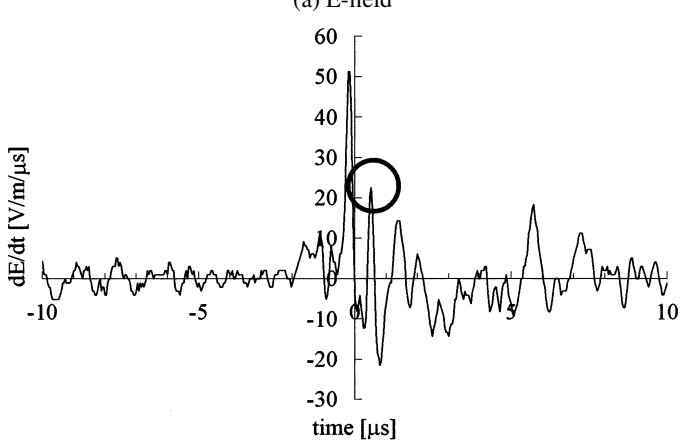

(b) Time derivative of E-field

図 4 Type B の電界波形及び電界時間微分波形

Fig. 4. An example of E-field and its time-derivative waveforms associated with "Type B" stroke.

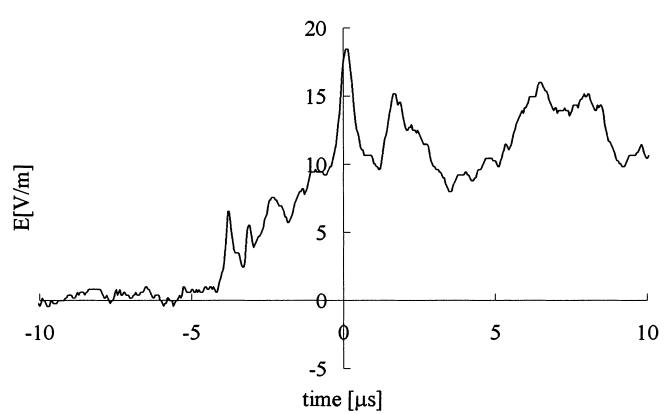

(a) E-field

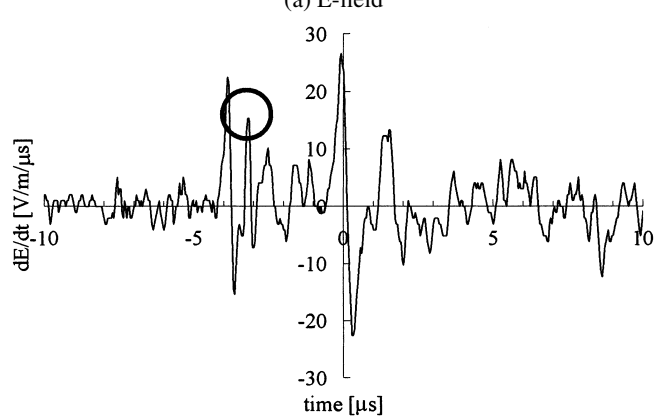

(b) Time derivative of E-field

図 5 Type C の電界波形及び電界時間微分波形

Fig. 5. An example of E-field and its time-derivative waveforms associated with "Type C" stroke.

の [ ]内に示している。

2005 年に志布志で得られた結果と文献(9)の結果を比べ ると, 各タイプの発生頻度は7\%以下の差で一致している。 電界波高值が雷撃点までの距離に逆比例すると仮定して雷 
表 1 負極性第一雷撃の電界及び $\mathrm{dE} / \mathrm{dt}$ 波形の パラメータ

Table 1. Parameters of E-field and dE/dt waveforms associated with negative first strokes.

\begin{tabular}{|c|c|c|c|c|}
\hline & & Type A & Type B & Type C \\
\hline \multirow{2}{*}{ Frequency } & number & $\begin{array}{c}75 \\
{[45]}\end{array}$ & $\begin{array}{l}110 \\
{[49]}\end{array}$ & $\begin{array}{c}83 \\
{[37]} \\
\ldots\end{array}$ \\
\hline & ratio[\%] & $\begin{array}{c}28 \\
{[34]}\end{array}$ & $\begin{array}{c}41 \\
{[37]}\end{array}$ & $\begin{array}{c}31 \\
{[28]}\end{array}$ \\
\hline \multirow{4}{*}{$\begin{array}{c}100 \mathrm{~km} \mathrm{E} \\
{[\mathrm{V} / \mathrm{m}]}\end{array}$} & $\begin{array}{c}\text { Average } \\
\text { (Standard deviation) }\end{array}$ & $\begin{array}{c}15(5.6) \\
{[7.6(2.8)]}\end{array}$ & $\begin{array}{c}20(6.1) \\
{[11(5.5)]}\end{array}$ & $\begin{array}{c}19(7.1) \\
{[8.7(3.7)]}\end{array}$ \\
\hline & $90 \%$ value & 9.3 & 11 & 10 \\
\hline & $50 \%$ value & $\begin{array}{c}13 \\
{[7.4]}\end{array}$ & 18 & $\begin{array}{c}16 \\
{[7.6]}\end{array}$ \\
\hline & $10 \%$ value & 23 & 27 & 31 \\
\hline \multirow{4}{*}{$\begin{array}{c}100 \mathrm{~km} \\
\mathrm{dE} / \mathrm{dt} \\
{[\mathrm{V} / \mathrm{m} / \mu \mathrm{s}]}\end{array}$} & $\begin{array}{c}\text { Average } \\
\text { (Standard deviation) }\end{array}$ & $\begin{array}{c}32 \\
(11) \\
(11)\end{array}$ & $\begin{array}{c}33 \\
(11) \\
(11)\end{array}$ & $\begin{array}{c}32 \\
(12)\end{array}$ \\
\hline & $90 \%$ value & 18 & 19 & 18 \\
\hline & $50 \%$ value & 32 & 31 & 31 \\
\hline & $10 \%$ value & 47 & 45 & 50 \\
\hline $\begin{array}{c}\text { Distance } \\
{[\mathrm{km}]}\end{array}$ & $\begin{array}{c}\text { Average } \\
\text { (Standard deviation) }\end{array}$ & $\begin{array}{c}82 \\
(33)\end{array}$ & $\begin{array}{c}94 \\
(32)\end{array}$ & $\begin{array}{c}95 \\
(32)\end{array}$ \\
\hline
\end{tabular}

[ ]: Results in (9)

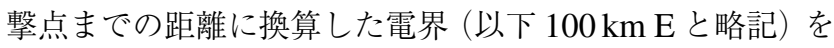
比較すると, Type B 及び Type C の 50\%值は Type A よりも $38 \%$ 及び $23 \%$ 各々大きくなり, これは文献 (9) と同様の傾 向を示している。また，文献(9)の結果と比較すると Type A の発生割合が減少し, 波高值の大きい Type B や Type C の発生頻度が少し高くなっている。これは, $100 \mathrm{~km} \mathrm{Eが,}$ 著者らの方が大きい事が原因の一つである。な抏，著者ら が解析対象とした雷撃の標定位置と観測局の平均的な距離 は, 文献(9)のデータのものより長いため, 志布志で得ら れた波高值の方が大きくなっている。

図 6 に, $100 \mathrm{~km}$ に規格化した $\mathrm{dE} / \mathrm{dt}$ ピーク值と, その雷 撃点から観測局までの距離の関係を示している。また, 図 7 は Type A の電界波形の立ち上がり時間と, 雷撃点から観 測局までの距離の関係を示している。立ち上がり時間は, 電界ピーク值の $30 \%$ の值から 90\%までの值を用いている。 図 6 及び図 7 では, 距離に対する依存性は殆ど認められな い。しかし後述するように，陸上を $300 \mathrm{~m}$ から $385 \mathrm{~m}$ 伝搬 した影響は無視できないため, 解析対象の雷撃は, 陸上伝 搬による波形変歪をほぼ同程度受けていると考えられる。

図 8 に, Type A, Type B 及び Type C の電界ピーク值と $\mathrm{dE} / \mathrm{dt}$ ピーク值の関係を示している。Type A 及び Type B では，ある程度の相関が見られるのに対し，Type Cでは相 関が認められない。両者の相関については，ファースト卜 ランジション (14) に対応する単独のパルスのみで構成される Type Aについてのみ，物理的な意味を見出すことができる。 文献(11)では, 雷撃の電界ピーク值を $\mathrm{dE} / \mathrm{dt}$ ピーク值で除 した值を特徵的な立ち上がり時間と定義している。Type A の 75 例に扔けるこの特徵的な立ち上がり時間は約 $220 \mathrm{~ns}$ であり，文献(9) では志布志の結果より約 20\%短い $160 \mathrm{~ns}$ であったと報告されている。これは，著者らの測定システ

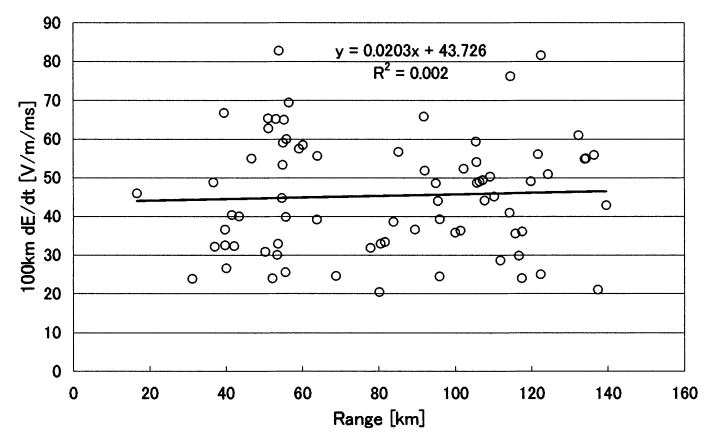

図 $6100 \mathrm{~km}$ に規格化した $\mathrm{dE} / \mathrm{dt}$ ピーク值と, 雷撃点から観測局までの距離の関係

Fig. 6. Peak dE/dt (range-normalized to $100 \mathrm{~km}$ ) dependent on the range for 305 first strokes.

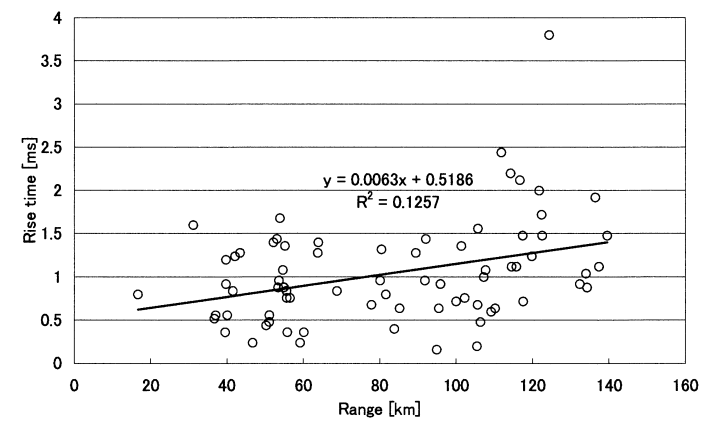

図 7 Type A に分類された電界波形の立ち上がり 時間と雷撃点から観測局までの距離の関係

Fig. 7. Rise time associated with "Type A" strokes, dependent on the range.

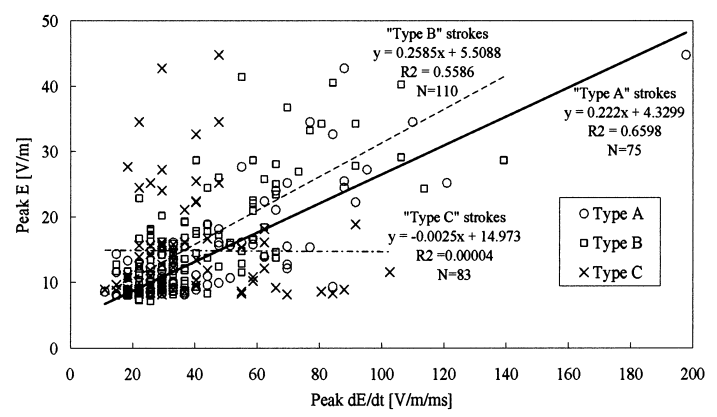

図 8 負極性第一雷撃の電界ピーク值と $\mathrm{dE} / \mathrm{dt}$ ピーク值

Fig. 8. Peak E vs. the (dominant) peak dE/dt for negative first strokes waveforms.

ムのサンプリング時間間隔が長いことや, 電磁波が海岸か ら観測点まで 300〜 375 m 陸上を伝搬した事による影響が 原因と考えられる。

$\langle\mathbf{3 \cdot 4}\rangle$ 負極性後続雷撃 表 2 に, 負極性後続雷撃の

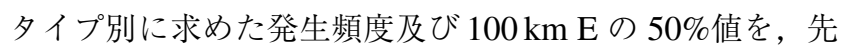
行する負極性第一雷撃の結果とともに示す。負極性第一雷 撃が Type A 以外を含む割合が高くても，それに続く後続 雷撃は 90\%以上が Type A となり, Type B や Type C のよ うな波形はまれである。これは，第一雷撃及び後続雷撃の 結合過程の相違を反映したものと考えられる。データ数が 
表 2 負極性後続雷撃の電界及び $\mathrm{dE} / \mathrm{dt}$ 波形

$$
\text { パラメータ }
$$

Table 2. Parameters of E-field and dE/dt waveforms associated with negative subsequent strokes.

\begin{tabular}{|c|c|c|c|c|}
\hline & & Type A & Type B & Type C \\
\hline \multirow{2}{*}{ Frequency } & number & $40[16]$ & 2 [9] & $2[8]$ \\
\hline & ratio[\%] & $91[48]$ & $4.6[27]$ & $4.6[24]$ \\
\hline \multirow[t]{2}{*}{$\begin{array}{c}100 \mathrm{~km} \mathrm{E} \\
{[\mathrm{V} / \mathrm{m}]}\end{array}$} & $\begin{array}{c}\text { Average } \\
\text { (Standard } \\
\text { deviation) }\end{array}$ & $8.9(3.4)$ & - & - \\
\hline & $50 \%$ value & $8.8[14]$ & - & - \\
\hline $\begin{array}{c}\text { Distance } \\
{[\mathrm{km}]}\end{array}$ & $\begin{array}{c}\text { Average } \\
\text { (Standard } \\
\text { deviation) }\end{array}$ & $\begin{array}{c}38[37] \\
(18)\end{array}$ & - & - \\
\hline
\end{tabular}

[ ]: Data for preceding first strokes

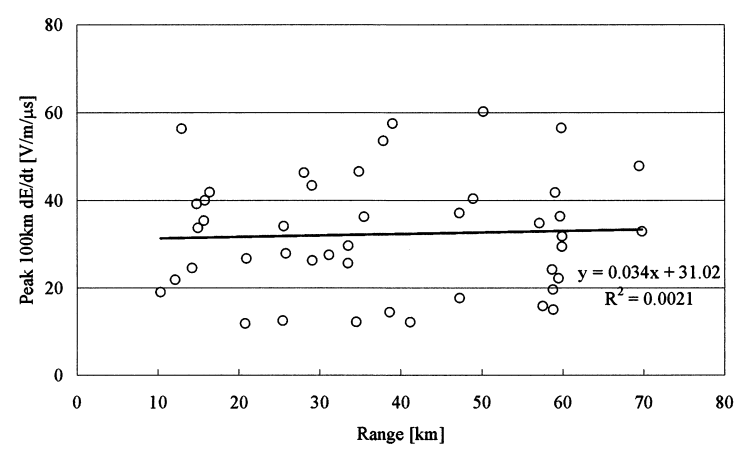

図 9 負極性後続雷撃における $100 \mathrm{~km} \mathrm{dE} / \mathrm{dt}$ ピークと 雷撃点から観測局までの距離の関係

Fig. 9. Peak dE/dt (range-normalized to $100 \mathrm{~km}$ ) dependent on the range for all 44 negative subsequent strokes.

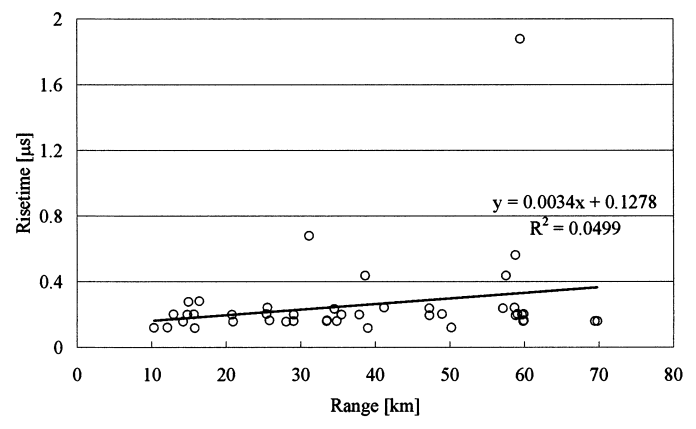

図 10 電界波形の立ち上がり時間と雷撃点から 観測局までの距離

Fig. 10. Rise time dependent on the range for negative subsequent strokes in our dataset.

全体で 44 例と少なく, Type B 及び Type C は 2 例しか得 られなかったため電界波高值に関する統計的な信頼性は低 いため，表には值を示していない。

図 9 及び図 10 に，負極性後続雷撃の雷撃点から観測局 までの距離と $100 \mathrm{~km} \mathrm{dE} / \mathrm{dt}$ の関係及び立ち上がり時間の関 係を示す。第一雷撃と同様, 雷撃点の距離と $\mathrm{dE} / \mathrm{dt}$ ピーク 及び立ち上がり時間に相関はほとんど見られない。

図 11 に, 負極性後続雷撃の Type A に打ける電界ピーク 值と $\mathrm{dE} / \mathrm{dt}$ ピーク值の関係を示す。先に述べた特徵的な立

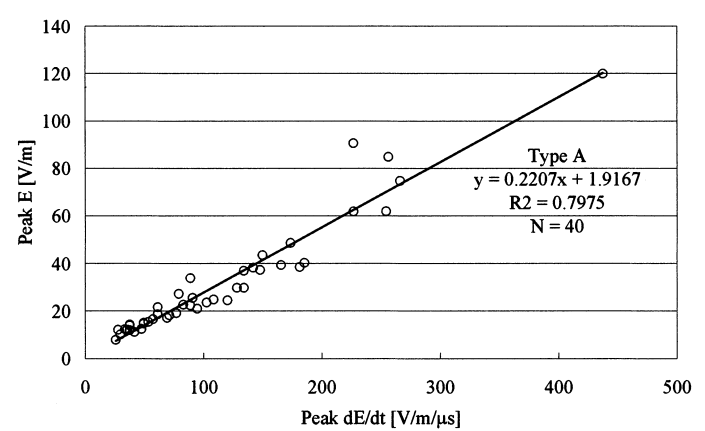

図 11 負極性後続雷撃の Type A における 電界ピーク值と $\mathrm{dE} / \mathrm{dt}$ ピーク值の関係

Fig. 11. Peak E vs. the (dominant) peak dE/dt for Type A negative subsequent strokes waveforms.

表 3 正極性第一雷撃の電界波形及び $\mathrm{dE} / \mathrm{dt}$ 波形の

$$
\text { パラメータ }
$$

Table 3. Parameters of E-field and dE/dt waveforms as-

\begin{tabular}{|c|c|c|c|c|}
\hline & & Type A & Type B & Type C \\
\hline \multirow{2}{*}{ Frequency } & number & 43 & 8 & 3 \\
\hline & ratio[\%] & 80 & 15 & 5.6 \\
\hline \multirow[t]{2}{*}{$\begin{array}{c}100 \mathrm{~km} \mathrm{E} \\
{[\mathrm{V} / \mathrm{m}]}\end{array}$} & $\begin{array}{c}\text { Average } \\
\text { (Standard } \\
\text { deviation) }\end{array}$ & $19(9.6)$ & - & - \\
\hline & $50 \%$ value & 16 & - & - \\
\hline $\begin{array}{c}\text { Distance } \\
{[\mathrm{km}]}\end{array}$ & $\begin{array}{c}\text { Average } \\
\text { (Standard } \\
\text { deviation) }\end{array}$ & $\begin{array}{c}92 \\
(19)\end{array}$ & - & - \\
\hline
\end{tabular}
sociated with positive first strokes.

ち上がり時間は $221 \mathrm{~ns}$ と, 第一雷撃のものとほぼ一致した。

$\langle\mathbf{3} \cdot 5\rangle$ 正極性第一雷撃 表 3 に, 正極性第一雷撃の 統計值を示す。正極性雷撃についても, 発生頻度は Type A が $80 \%$ と大部分を占める。Type B や Type C のデー夕数が 各々 8 例及び 3 例と少なく, $100 \mathrm{~km} \mathrm{E}$ 等に関する統計的な 信頼性は低いため，表には值を示していない。

図 12 及び図 13 に，正極性雷撃の雷撃点から観測局まで の距離と $100 \mathrm{~km} \mathrm{dE} / \mathrm{dt}$ ピーク值及び立ち上がり時間の関係 を示す。図 12 では $\mathrm{R}^{2}$ が他の例よりも多少大きく, 両者に 正の相関が見受けられるが，図 13 の電界波形の立ち上が り時間と雷撃点から観測局までの距離には有意な相関は認 められない。測定系は電界の絶対值が基準值を超えた時点 でトリガしているので, トリガレベル付近にピーク值をも つデータを, 雷撃点までの距離が $100 \mathrm{~km}$ の場合に換算し た場合には，雷撃点までの距離が長いほど換算した波高值 は大きくなる。正極性雷撃で対象としたデータには, トリ ガレベル付近にピーク值をもつ例が多い上に, 立ち上り時 間は伝搬距離の影響を殆ど受けなかったため, 雷撃点から 観測局までの距離と $100 \mathrm{~km} \mathrm{dE} / \mathrm{dt}$ ピーク值の正の相関が多 少強くなったと考えられる。海上を伝搬することで高周波 成分が減衰することの影響であれば，負の相関が認められ るはずである。

図 14 に，正極性第一雷撃の Type A に分類された電界 ピーク值と $\mathrm{dE} / \mathrm{dt}$ ピーク值の関係を示す。先に述べた特徽 


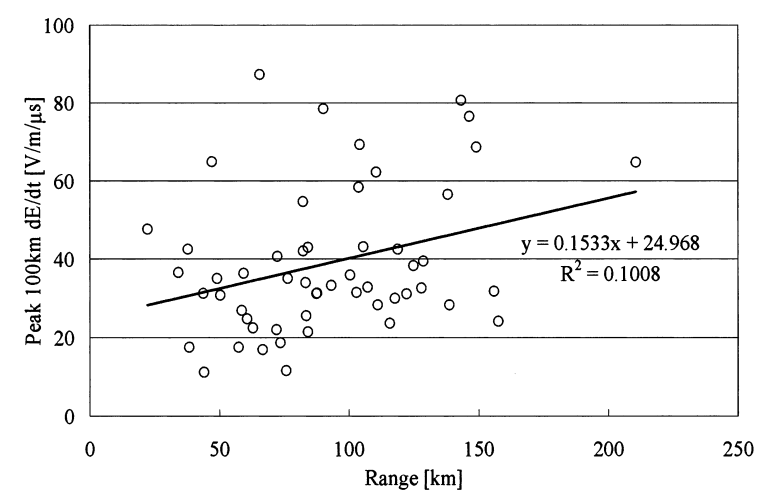

図 12 正極性第一雷撃の $100 \mathrm{~km} \mathrm{dE} / \mathrm{dt}$ ピーク值と 雷撃点から観測局までの距離の関係

Fig. 12. Peak dE/dt (range-normalized to $100 \mathrm{~km}$ ) dependent on the range for 54 positive first strokes.

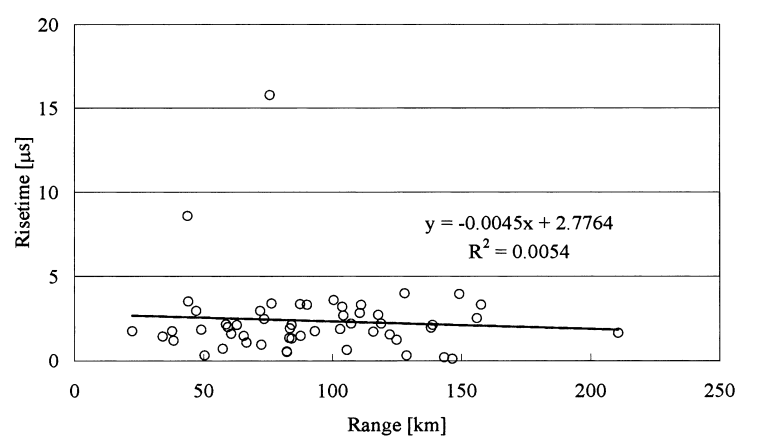

図 13 正極性雷撃における電界波形の立ち上がり時間と 雷撃点から観測局までの距離の関係

Fig. 13. Rise time dependent on the range for 54 positive strokes.

的な立ち上がり時間は $292 \mathrm{~ns}$ となり，負極性雷撃に対する ものよりも大きい值となった。これは，正極性雷撃に伴っ て発生した電界波形では, 負極性雷撃と比較して立ち上が り時間が長いことが反映されていると考えられる。

以上の検討の結果, $\mathrm{dE} / \mathrm{dt}$ 波形の最大ピーク時刻付近に別 のパルスが存在する雷撃 (Type B と Type C) は, 負極性第 一雷撃では 70\%に達するものの, 負極性後続雷撃では $9 \%$, 正極性雷撃では $20 \%$ と低い值になり, 負極性第一雷撃に関 しては, これらの雷撃の電界のピーク值は, 最大ピーク時刻 付近に別のパルスが存在しない Type A よりも，100 kmに 規格化した電界ピーク值は 10３0\%大きくなる事が判明し た。またこれれらの結果に海上を電磁波が伝搬することによ る高周波成分の減衰が及ぼす影響は殆ど認められなかった。

落雷位置標定システムでは, 観測された磁界波形の波高 值から電流波高值を推定するため (1)，電磁界の波高值が大 きい Type B や Type C の雷撃電流波高值が大きく推定され ることになる。JLDN で推定された南九州の南東海域への 負極性第一雷撃で陸上への雷撃よりも電流值が大きく推定 され，負極性後続雷撃や正極性雷撃でこの傾向が認められ ないのは, 負極性後続雷撃や正極性雷撃では発生割合の低 い Type B や Type C の電界波形の発生頻度が負極性第一雷

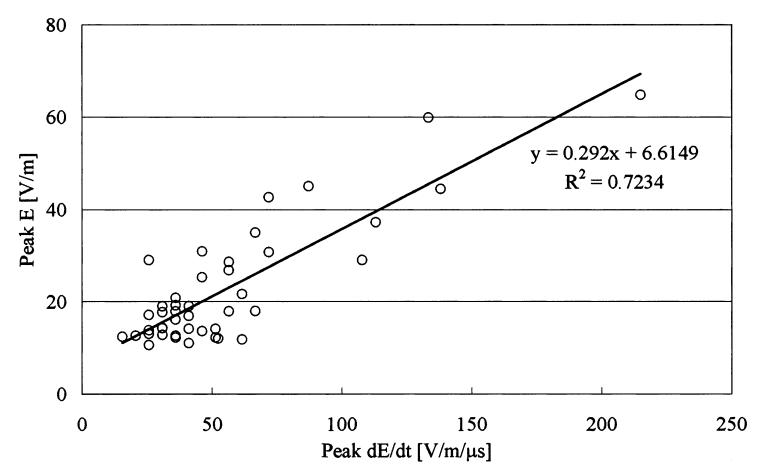

図 14 正極性第一雷撃の Type A における, 電界 ピーク值と $\mathrm{dE} / \mathrm{dt}$ ピーク值の関係

Fig. 14. Peak E vs. the (dominant) peak $\mathrm{dE} / \mathrm{dt}$ for positive Type A strokes.

撃では高いことが原因の一つと考えられる。前述したよう に, Type A, Type B 及び Type C の電界波形の発生には, 下向きのリーダと上向きの放電との結合過程 (attachment process）で発生する現象が関連するものと推定されている ため, 海上と陸上への負極性第一雷撃で落雷位置標定シス テムの電流值が異なるのは, 物理的には結合過程に一因が ある事が示されたと考えている。

\section{4. 結言}

九州南部で発生する雷の電流波高值を, JLDNにより得ら れた結果に基づいて検討すると共に, 海上への雷撃に伴っ て発生した電界波形の特徵について調査した。この結果, 以下の上うな知見が得られた。

（1） 2006 年に南九州で発生した雷撃の推定電流波高値 を解析した結果, 負極性第一雷撃の電流波高值は, 陸上よ りも海上の方が 13\%大きいという結果を得た。一方, 負極 性後続雷撃及び正極性雷撃には, 陸上と海上で推定電流值 に有意な差は認められなかった。これは, アメリカ南部及 び東部の雷に関する NLDN の測定結果と同様の傾向であっ た(7)。

（2）志布志湾沿岸の海上に発生した負極性第一帰還雷撃 に伴う垂直電界波形を解析した結果, $\mathrm{dE} / \mathrm{dt}$ 波形の最大ピー ク時刻付近に別のパルスが存在する雷撃が全体の約 70\%あ り,これらの $100 \mathrm{~km}$ に規格化した電界ピーク值は, パル スが発生していない雷撃に比べて 10〜30\%大きかった。こ れは文献 (9) と同様の傾向である。

（3）負極性後続雷撃及び正極性雷撃に伴う垂直電界波 形を解析したもののうち, $\mathrm{dE} / \mathrm{dt}$ 波形の最大ピーク時刻付近 に別のパルスが存在する雷撃はほとんど存在しないことが 分かった。

（4）以上の検討から, 落雷位置標定システムにより南 九州の南東海域で得られた負極性第一雷撃でのみ, 陸上へ の雷撃よりも電流值が大きく推定されるのは, 負極性後続 雷撃や正極性雷撃では発生割合が低く, 結合過程にその発 生原因があると考えられる, 最大ピーク時刻付近に別のパ 
ルスが存在する電界の時間微分波形の発生頻度が負極性第

一雷撃では高いことが原因の一つと考えられる。

(平成 19 年 2 月 27 日受付, 平成 19 年 5 月 23 日再受付)

\section{文献}

(1) K.L. Cummins, M.J. Murphy, E.A. Bardo, W.L. Hiscox, R.B. Pyle, and A.E Pifer: "A combined TOA/MDF technology upgrade of the U. S. National Lightning Detection Network", J. Geophys. Res., Vol.103, No.D8, pp.90359044 (1998)

(2) K.L. Cummins, E.P. Krider, and M.D. Malone: "The US National Lightning Detection Network and applications of cloud-to-ground lightning data by electric power utilities", IEEE Trans. Electromagnetic Compatibility, Vol.EMC-40, pp.465-480 (1998)

(3) W. Schulz, K.L. Cummins, G. Diendorfer, and M. Dorninger: "Cloudto-ground lightning in Austria: A 10-year study using data from a lightning location system", J. Geophys. Res., Vol.110, No.D09101, dori: 10.1029/2004JD005332 (2005)

(4) T. Suda, T. Shindo, S. Yokoyama, S. Tomita, A. Wada, A. Tanimura, N. Honma, S. Taniguchi, M. Shimizu, T. Sakai, Y. Sonoi, K. Yamada, M Komori, K. Ikesue, and K. Toda: "Lightning Occurrence Data Observed with Lightning Location System Operated by Power Utilities in Japan”, International Conference on Lightning Protection (ICLP), No.2b.3, pp.111116 (2002)

( 5 ) N. Honma, F. Suzuki, Y. Miyake, M. Ishii, and S. Hidayat: "Propagation Effect on field waveforms in relation to time-of-arrival technique in lightning location”, J. Geophys. Res., Vol.103, No.D12, pp.14141-14145 (1998)

(6) K. Shinjo, T. Wakai, T. Sakai, and M. Ishii: "Accuracy of LLP system and lightning frequency map evaluated from transmission line faults", T. IEE Japan, Vol.117-B, No.11, pp.1448-1457 (1997-11) (in Japanese)

新庄一雄・岩井武夫・酒井 勉・石井 勝:「落雷位置標定システム の精度と落雷頻度マップの送電線トリップ事故に基づく評価」, 電学 論 B, 117, 11, pp.1448-1457 (1997-11)

(7) K.L. Cummins, J.A. Cramer, W.A. Brooks, and E.P. Krider: "On the effect of land: Sea and other earth surface discontinuities in LLS-Inferred lightning parameters", VIII International Symposium on Lightning Protection (2005)

(8) V.A. Rakov and M.A. Uman: Lightning physics and effects, p.137, Cambridge University Press, Cambridge (2003)

(9) N.D. Murray, E.P. Krider, and J.C. Willett: "Multiple pulses in $\mathrm{dE} / \mathrm{dt}$ and the fine-structure of $\mathrm{E}$ during the onset of first return strokes in cloud-to-ocean lightning", Atmospheric Research, Vol.76, pp.455-480 (2005)

(10) J.C. Willett, E.P. Krider, and C. Leteinturier: "Submicrosecond field variations during the onset of first return strokes in cloud-to-ground lightning", $J$. Geophys. Res., Vol.103 No.D8, pp.9027-9034 (1998)

(11) J.C. Willett and E.P. Krider: "Rise times of impulsive high-current processes in cloud-to-ground lightning", IEEE Trans. Antennas Propagat., Vol.AP-48, pp.1442-1451 (2000)

(12) M. Ishii, M. Saito, F. Fujii, J. Hojo, M. Matsui, N. Itamoto, and K. Shinjo: "LEMP from Lightning Discharges Observed by JLDN", IEEJ Trans. PE, Vol.125, No.8, pp.765-770 (2005)

(13) K. Michishita, T. Ochiai, and K. Ikesue: "Estimation of lightning current parameters based in measured electric field", IWHV2004, ED-04-139, SP04-51, HV-04-81 (2004)
(14) C.D. Weidman and E.P. Krider: "The fine structure of lightning return stroke wave forms", J. Geophys. Res., Vol.83, No.C12, pp.6239-6247 (1978)

道 下 幸 志 (正員) 1962 年 9 月 24 日生。 1991 年 3 月東京

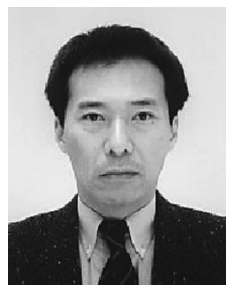
大学大学院工学系研究科電気工学専攻博士課程終 了。工学博士。同年 4 月静岡大学助手, 1994 年 4 月同助教授，現在に至る。主として，雷に起因す る環境電磁工学に関する研究に従事。IEEE, AGU Member., 日本大気電気学会, 電気設備学会会員。

長 綱 望 (学生員) 1981 年 7 月 27 日生。 2006 年 3 月静

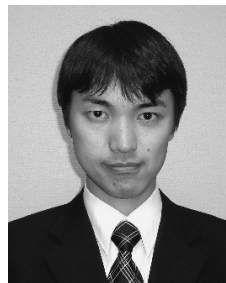
岡大学工学部電気・電子工学科卒業。同年 4 月静 岡大学大学院工学研究科入学, 現在に至る。主と して，雷性状に関する研究に従事。

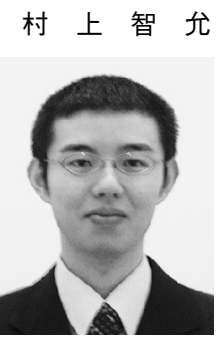

（正員） 1982 年 9 月 8 日生。 2005 年 3 月静岡大 学工学部電気電子工学科卒業。2007 年 3 月静岡 大学大学院工学研究科修了, 現在に至る。主とし て，雷性状に関する研究に従事。

原 田 貴 司 (正員) 1965 年 4 月 7 日生。1988 年 3 月九州工

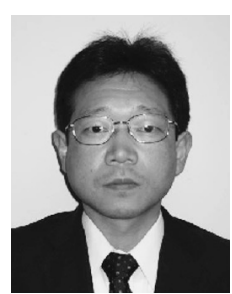
(正員) 1965 年 4 月 7 日生。1988 年 3 月九州工 業大学工学部電気工学科卒業。同年 4 月九州電力 (株) 入社。現在, 同社総合研究所勤務。主とし て，配電線の信頼性向上に関する研究に従事。 